\title{
Editorial
}

\section{A dinâmica da psicopatologia: o caso da maconha}

\author{
Manoel Tosta Berlinck*
}

Neste início de ano de 2014 a imprensa abriu espaços para tratar da maconha (marijuana, cannabis sativa). A novidade, em resumo, é que ela está deixando de ser droga ilícita e, pouco a pouco, passa a ser droga lícita.

Só nos Estados Unidos da América 19 Estados se preparam para legalizar o consumo da erva, por decisão democrática resultante de consultas ao eleitorado. Neste caso, o povo é favorável à descriminalização da maconha e, nos EUA, a voz do povo perde só mesmo para a voz de Deus. Em vários deles, como no estado de New York (EUA), a maconha passou a ser considerada medicamento, como já havia ocorrido na Califórnia (EUA), e só pode ser consumida legitimamente acompanhada de receita médica.

A Organização Mundial de Saúde (OMS), organismo da ONU, refere-se a plantas medicinais como espécies vegetais a partir das quais produtos de interesse terapêutico podem ser obtidos e usados na espécie humana como medicamento.

Recentemente perguntei a um respeitável médico qual seria a doença que a maconha combateria. Ele deu uma boa risada e disse que ainda não tinha lido uma bula. Será que

\footnotetext{
* Pontifícia Universidade Católica de São Paulo - PUC-SP (São Paulo, SP, Brasil)
} 
no estado de New York (EUA) já há bulas fornecidas por laboratórios farmacêuticos acompanhando frascos com maconha?

Em outras partes, como nos Estados de Colorado (EUA) e Washington (EUA), o consumo da maconha foi liberado para fins recreativos para maiores de 21 anos.

Talvez a escassez de recreação seja uma doença assolando os moradores de New York, a ponto de se transformar numa doença tratável pelo consumo de maconha.

No Colorado, a compra é limitada a 28 gramas que podem custar mais de R\$ 500,00 (quinhentos reais). Quem não tiver carteira de identidade pode comprar 7 gramas por dia. O Colorado é o primeiro lugar no mundo onde a maconha é regulada do plantio, limitado a seis pés por pessoa, à venda.

Estimativas apontam que, anualmente, o Colorado economizará R\$ 27 bilhões no combate contra as drogas e arrecadará cerca de R $\$ 160$ milhões em impostos sobre o comércio. Desse valor, cerca de R $\$ 58$ milhões irão para a construção de escolas.

Há mais de um ano, já era possível fumar maconha legalmente no Colorado sem motivos médicos, desde que atendidas certas condições: não usar a droga em lugares públicos, não dirigir após fumar, não dar maconha para menores de 21 anos e não levar a erva para fora do Estado. Essas restrições se mantêm. Em Denver, especificamente, a Câmara local aprovou lei permitindo que uma pessoa fume maconha à vista do público, desde que seja dentro dos limites de sua propriedade.

O comércio da erva sofre dificuldades. Por exemplo, os bancos relutam em receber depósitos de lojas que vendem maconha. Apesar de colocarem caixas eletrônicos no interior das próprias lojas, recusam os depósitos temendo punição do governo federal, pois podem ser acusados de colaboração em comércio ilícito, já que o comércio da maconha é crime federal.

No Brasil, em decisão inédita, o juiz Frederico Ernesto Cardoso Maciel, do Distrito Federal, absolveu um homem flagrado traficando 52 trouxas de maconha por considerar inconstitucional a proibição dessa droga. (O Estado de S. Paulo de 20/01/2014). A sentença, da $4^{\text {a }}$ Vara de Entorpecentes de Brasília, foi dada em outubro de 2013, mas o caso só ganhou repercussão na comunidade jurídica no dia 16 de janeiro de 2014, quando o Tribunal de Justiça do Distrito Federal colocou a ação em pauta para analisar a apelação do Ministério Público.

Se a sentença do juiz for considerada constitucional passará a ser um importante precedente jurídico, criando jurisprudência a favor do tráfego e do consumo do baseado.

No Uruguai, a regulamentação da lei 19.172 - que cria o primeiro mercado estatal e legal da maconha no mundo - ainda é analisada por organismos como os ministérios da Saúde, Interior, Gado, Economia, Relações Exteriores e Educação e Cultura.

Um grupo de trinta pessoas trabalha nos detalhes do consumo para fins recreativos da droga, o que deve ocorrer em abril de 2014. A regulamentação do consumo para uso medicinal da droga demorará três meses mais. 


\section{EDITORIAL}

Segundo a lei, os uruguaios e estrangeiros residentes no Uruguai poderão comprar até 40 gramas da maconha em farmácias, sob prévia inscrição num registro de consumidores. Também se habilitarão clubes especializados e a possibilidade do cultivo próprio. A produção da droga será controlada pelo Estado, que concederá licenças a empresas por meio do Instituto de Regulação e Controle do Cannabis (IRCCA).

A venda da maconha pelo Estado ainda não começou no Uruguai, mas, segundo o jornal $O$ Estado de S. Paulo de 25 de janeiro de 2014 (p. A15), pesquisadores e laboratórios de Canadá, EUA, Espanha e Holanda estudam a legislação aprovada em dezembro para investir em estudos científicos sobre a droga. Além de fazer pesquisa no país, algumas empresas estudam exportar a erva.

\section{Bom negócio!}

A maconha deixa, assim, de ser um símbolo da oposição ao capitalismo, como ocorreu nos anos 1960, com os hippies, e passa a ser mais um bem de consumo proporcionando grandes lucros.

Brevemente haverá anúncios na TV e em outros meios de comunicação promovendo o consumo da maconha com marcas. Os impostos serão semelhantes aos cobrados no consumo do tabaco. As embalagens promoverão ganhos adicionais para as empresas de propaganda e marketing.

Enfim, é fácil imaginar que países mais conservadores, que mantiverem uma legislação contrária à produção, comercialização e consumo da maconha, continuarão "emergentes".

\section{E a psicopatologia?}

A descriminalização da maconha coloca algumas importantes questões para a psicopatologia, pois se trata de droga psicotrópica.

O que é uma droga psicotrópica? É aquela que contém substância química que age principalmente no sistema nervoso central, alterando a função cerebral e temporariamente mudando a percepção, o humor, o comportamento e a consciência. Essa alteração pode ser proporcionada para diversos fins: recreacionais (alteração proposital da consciência), científicos (funcionamento da mente) ou médico-farmacológicos.

Tais alterações subjetivas da consciência e do humor afetam o ser humano e são fonte de prazer, servindo para criar uma melhora nos sentidos e estados já 
experimentados na natureza (por exemplo, o aumento da concentração), ou uma mudança na perspectiva mental, podendo aumentar também a criatividade.

Acreditou-se, por muito tempo, que a maconha fosse uma droga que intoxicava, como a cocaína ou o tabaco. Parece, entretanto, que este não é o caso.

Por que, então, proibir o que promove prazer?

Sabe-se que o prazer é um afeto perigoso, pois, quando excessivo, pode levar à morte. Porém, resta saber se a maconha é mortífera ou o mortífero se deve à ânsia pelo prazer. Há overdose de maconha, como ocorre com outras drogas? Ou seu consumo excessivo leva somente ao relaxamento e ao sono?

Enfim, o que interessa é saber por que uma substância prazerosa e, afinal, aparentemente inofensiva e até benéfica (Super Interessante, agosto de 1995) foi considerada por tanto tempo ilícita, e agora deixa de ser, sem qualquer razão aparentemente psicopatológica.

Tudo indica que as razões psicopatológicas são desculpas para o controle de uma droga que poderia competir com, por exemplo, o tabaco ou o álcool. Como bem observa Barak Obama, presidente dos EUA, a maconha não é mais perigosa do que o álcool. Ele não disse, entretanto, que o álcool (ou o tabaco) é mais nocivo que o baseado.

\section{Manoel Tosta Berlinck}

Sociólogo; Psicanalista; Ph.D. (Cornell University, Ithaca, N.Y., USA); Professor da Escola de Administração de Empresas de São Paulo (EAESP) da Fundação Getúlio Vargas (19691972); Professor da Universidade Estadual de Campinas - Unicamp (Campinas, SP, Br.) (1972--1992); Sócio-fundador do Centro Brasileiro de Análise e Planejamento - Cebrap (1969- ); Diretor do Instituto de Filosofia e Ciências Humanas - IFCH da Unicamp (19721976); Professor do Departamento de Psicologia do Desenvolvimento da Faculdade de Ciências Humanas e da Saúde da Pontifícia Universidade Católica de São Paulo - PUC-SP (São Paulo, SP, Br); Professor do Programa de Estudos Pós-Graduados em Psicologia Clínica da Faculdade de Ciências Humanas e da Saúde da Pontifícia Universidade Católica de São Paulo - PUC-SP, onde dirige, desde 1995, o Laboratório de Psicopatologia Fundamental; Presidente da Associação Universitária de Pesquisa em Psicopatologia Fundamental - AUPPF (2002- -2012); Editor responsável de Pulsional Revista de Psicanálise (1987-2009) e da Revista Latinoamericana de Psicopatologia Fundamental; Membro da World Association of Medical Editors - WAME (Associação Mundial de Editores Médicos) e do Council of Science Editors - CSE; Diretor da Livraria Pulsional - Centro de Psicanálise (1987-2009) e da Editora Escuta (1987-2009); Autor de Psicopatologia Fundamental (2000) e de Erotomania com German E. Berrios (2009), entre outros livros e numerosos artigos.

Rua Tupi, 397/103

01233-001 São Paulo, SP

Fonefax: 55113825.8573

e-mail: mtberlin@uol.com.br 